\title{
THE STANDARD OF PROOF IN DISCIPLINARY PROCEEDINGS: SOLICITORS REGULATION AUTHORITY v SHARIF (2019)
}

\author{
John Hatchard*
}

The January 2019 ruling of the Solicitors Disciplinary Tribunal in Solicitors Regulation Authority $v$ Sharif ${ }^{1}$ highlighted the care that legal practitioners must take in order to satisfy their anti-money laundering obligations and the serious consequences of any failure to do so. This is the subject of a separate note in this issue of the Denning Law Journal. ${ }^{2}$ However, the Solicitors Disciplinary Tribunal applied the criminal standard of proof in the case. The question as to whether this is now the appropriate approach is the subject of this note.

\section{SOLICITORS AND THE STANDARD OF PROOF AT DISCIPLINARY HEARINGS}

The current framework for dealing with disciplinary matters involving solicitors is as follows. In the case of less serious allegations, the Solicitors Regulation Authority (SRA) enjoys its own disciplinary powers and can impose a range of administrative penalties. The Solicitors Disciplinary Tribunal acts as an appellate body. Where its powers are considered insufficient, the SRA brings the case to the Solicitors Disciplinary Tribunal. Thus, the Tribunal acts as the first instance decision-maker in cases involving the most serious allegations relating to alleged professional misconduct against individual solicitors and firms. The Tribunal has wide sanctioning powers including issuing a reprimand, imposing an unlimited fine or ordering the removal of an individual solicitor from practice. Given the serious nature of the allegations against Mr Sharif concerning the failure to comply with his anti-money laundering obligations, the SRA brought the case to the Tribunal.

As regards the standard of proof in disciplinary cases involving solicitors, there is a 'mixed' approach. In cases heard and determined by the SRA, the civil

\footnotetext{
Professor of Law, Buckingham Law School, and Co-Director of the University of Buckingham Centre for Extractive Energy Studies.

1 Solicitors Regulation Authority v Sharif Case 11805-2018 (Solicitors Disciplinary Tribunal, 2019).

2 See p 194.
} 


\section{THE STANDARD OF PROOF IN DISCIPLINARY PROCEEDINGS: SOLICITORS REGULATION AUTHORITY v SHARIF (2019)}

standard of proof (balance of probabilities) is applied. As regards the Tribunal, section 46 of the Solicitors Act 1974 provides it with a wide discretion to regulate its own procedure. The longstanding position of the Law Society of England and Wales (the Law Society) is that the Tribunal should apply the criminal standard of proof (beyond reasonable doubt), a key reason for doing so being the 'significant impact that adverse decisions can have on individuals subject to tribunal proceedings.' ${ }^{3}$ Accordingly, the Tribunal ruled that the SRA was required to prove the allegations against $\mathrm{Mr}$ Sharif beyond reasonable doubt. ${ }^{4}$

This mixed approach can lead to a curious situation as illustrated by the case of Solicitors Regulation Authority $v$ Solicitors Disciplinary Tribunal. ${ }^{5}$ Here Huseyin Arslan was the subject of disciplinary proceedings before the SRA. Applying the civil standard of proof, the SRA adjudicator found allegations of misconduct proved against Mr Arslan and ordered that a sanction be imposed. $\mathrm{Mr}$ Arslan then applied to the Tribunal for a review of the decision of the adjudicator. In considering the matter, the Tribunal applied the criminal standard of proof and on the facts revoked the order.

In the High Court, the SRA sought to challenge the ruling of the Tribunal, arguing, inter alia, that 'the Tribunal erred in law in holding that the criminal standard of proof should be applied'. ${ }^{6}$ Leggatt J agreed with this submission. The court was then invited to give an opinion on the standard of proof to be applied by the Tribunal when acting as a first instance decision-maker. Leggatt $\mathrm{J}$ noted that 'the climate and approach to professional regulation'7 had changed since the High Court decision In Re A Solicitor ${ }^{8}$ and the Privy Council decision in Campbell $v$ Hamlet (Trinidad and Tobago). ${ }^{9}$ In the former, Lord Lane in the Divisional Court held that the criminal standard was applicable where "what is alleged is tantamount to a criminal offence'. ${ }^{10}$ In Campbell, a case also involving a legal practitioner, the Privy Council went further and held that 'the criminal

\footnotetext{
3 The Law Society, 'The Standard of Proof Applied by the Solicitors Disciplinary Tribunal' (The Law Society, 2017) <https://www.lawsociety.org.uk/news/documents/ standard-of-proof-discussion-paper/> accessed 10 June 2019, para 2.3.

4 Ibid., para 12.

5 Solicitors Regulation Authority v Solicitors Disciplinary Tribunal [2016] EWHC 2862 (Admin).

6 Ibid., para 23.

7 Ibid., para 49.

8 In Re A Solicitor [1993] QB 69.

9 Campbell v Hamlet (Trinidad and Tobago) [2005] UKPC 19.

10 Re A Solicitor (n 9) para 81.
} 
standard of proof is the correct standard to be applied in all disciplinary proceedings concerning the legal profession .....'11

Leggatt $\mathrm{J}$ considered these decisions were 'ripe for re-consideration'12 but declined the invitation to express a concluded view of the point in the instant case. Sir Brian Leveson agreed with this approach but underlined the need for 'a re-evaluation of the approach to disciplinary measures intended to protect the public'. ${ }^{13}$ On the facts, the High Court quashed the decision of the Tribunal.

\section{NEED FOR A CHANGE?}

The standard of proof used at disciplinary proceedings of professional bodies has been the subject of considerable discussion in recent years with a clear trend being towards the adoption of the civil standard. For example, the Medical Practitioners Tribunal Service, which is a statutory committee of the General Medical Council, has adopted the civil standard of proof where there are any disputed facts in disciplinary proceedings against medical practitioners. ${ }^{14}$ Perhaps more significant is the position of the Bar Standards Board (BSB). In 2017, the BSB issued a consultation paper entitled 'Review of the Standard of Proof Applied in Professional Misconduct Proceedings' ${ }^{15}$ in which it requested views from the profession and the public on the appropriate standard of proof in misconduct proceedings. At that time, the position was similar to disciplinary matters involving solicitors. Thus the BSB's Professional Conduct Committee was empowered to deal with potential breaches of the BSB Handbook by way of administrative sanctions, the applicable standard of proof being the civil standard. In more serious cases, the matter was referred to a Disciplinary Tribunal which applied the 'criminal standard of proof when deciding charges of professional misconduct and in deciding whether the disqualification condition has been established'. ${ }^{16}$

11 Campbell v Hamlet (Trinidad and Tobago) (n 10) para 16.

12 Ibid., para 49.

13 Ibid., para 73.

14 See Medical Practitioners Tribunal Service, 'Resource for Doctors: Medical Practitioners Tribunals' (MPTS, 2019) <https://www.mpts-uk.org/-/media/mpts-documents/ dc11585-resource-for-doctors-medical-practitioners-tribunals_pdf-76539010.pdf $>$ accessed 15 April 2019, p 4.

15 Bar Standards Board, 'Review of the Standard of Proof Applied in Professional Misconduct Proceedings: Consultation Paper' (Bar Standards Board, May 2017) <https:// www.barstandardsboard.org.uk/media/1830289/sop_consultation_paper.pdf $>$ accessed 15 April 2019.

16 Disciplinary Tribunal Regulations 2014, Regulation E143. 


\section{THE STANDARD OF PROOF IN DISCIPLINARY PROCEEDINGS: SOLICITORS REGULATION AUTHORITY v SHARIF (2019)}

Following the consultation, the BSB issued a response that carefully reviewed the issue of the appropriate standard of proof. The BSB concluded that:

Overall, we take the view, as expressed by some in favour of change, that it is self-evident that the civil standard provides better public protection given that it allows for sanctions to be imposed where it is more likely than not there has been a serious breach of an individual's professional obligations. In principle, it seems difficult to argue against this without a clear justification for saying that the criminal standard provides better protection. We do not consider that such a clear justification exists. ${ }^{17}$

In November 2017, the BSB announced that it had decided to change the standard of proof in all cases to the civil standard with the Chair of the BSB noting that this would be 'an important step forward in the BSB's ongoing work to modernise the regulation of the Bar in the public interest ${ }^{18}$ (emphasis added). Accordingly, as from 1 April 2019 the BSB applies the civil standard of proof rather than the criminal standard in cases where barristers, and others regulated by the BSB, face disciplinary proceedings for professional misconduct. ${ }^{19}$

In 2017, the Law Society issued its own consultation paper $^{20}$ seeking the views of solicitors on the subject. It recognised there was an inherent difficulty in classifying disciplinary proceedings as being civil or criminal in nature and noted

17 Bar Standards Board, 'BSB Standard of Proof Consultation - BSB Response' (Bar Standards Board, July 2017) < https://www.barstandardsboard.org.uk/media/1923922/ standard_of_proof_consultation_-_bsb_response_-_final.pdf $>$ accessed 15 April 2019, para 38.

18 Bar Standards Board, 'Civil Standard of Proof Set to be Adopted for Professional Misconduct Proceedings for Barristers' (Bar Standards Board, 24 November 2017) $<$ https://www.barstandardsboard.org.uk/media-centre/press-releases-and-news/civilstandard-of-proof-set-to-be-adopted-for-professional-misconduct-proceedings-forbarristers/> accessed 10 June 2019.

19 Somewhat confusingly in the case of veterinary surgeons, the Royal College of Veterinary Surgeons Disciplinary Committee Procedure Guidance states that the standard of proof to be applied by the Disciplinary Committee is that specified in the (Procedure and Evidence Rules) Order of Council 2004. See Royal College of Veterinary Surgeons, 'Disciplinary Committee Procedure Guidance' (RCVS, 27 September 2013) <https:// www.rcvs.org.uk/document-library/disciplinary-committee-procedure-guidance/> accessed 10 June 2019, para 13: 'The standard [of proof] is that the Disciplinary Committee should be "satisfied to the highest civil standard of proof, so that it is sure" (which is tantamount to applying the "criminal standard")' (emphasis in the original).

20 The Law Society (n 4). 
that the European Court of Justice has viewed such proceedings as being of a hybrid nature. ${ }^{21}$ Indeed, in the consultation paper, the Law Society not only explored the arguments for and against the criminal and the civil standard but also noted possible 'hybrid' options. One option based on the American Bar Association Model Rules for Lawyer Disciplinary Enforcement was to introduce an intermediate standard, i.e. requiring 'clear and convincing evidence'. ${ }^{22}$ The use of a 'sliding scale approach' ${ }^{23}$ was also noted. This is used by several international sports disciplinary bodies and provides for a flexible approach to the standard of proof depending on the seriousness of the allegation. ${ }^{24}$

In the event, the result of the consultation was that $90 \%$ of solicitors responding were in favour of maintaining the status quo and this remains the position.

\section{TOWARDS A COMMON APPROACH TO THE STANDARD OF PROOF?}

Given that the standard of proof in disciplinary proceedings of other professional bodies is overwhelmingly the civil standard, the Solicitors Disciplinary Tribunal is placed in an anomalous position. As Leggatt $\mathbf{J}$ noted in Solicitors Regulation Authority $v$ Solicitors Disciplinary Tribunal 'the present situation in which the Tribunal, when acting as a primary fact-finder applies a different standard of proof from that which the SRA applies when carrying out that role is unsatisfactory and illogical'. ${ }^{25}$ Given its wide-ranging disciplinary powers there is rightly concern over the need to ensure a suitably high standard of proof in cases where there is an allegation of criminal conduct or where a solicitor's livelihood is at stake. However,

\section{Albert and Le Compte v Belgium [1983] 5 EHRR 533.}

${ }^{22}$ An intermediate standard has been favoured by several courts in the Commonwealth when considering the appropriate standard of proof in election petition cases: see in particular the Supreme Court of Kenya decision in Odinga v Independent Electoral and Boundaries Commission [2017] eKLR. See also the discussion in John Hatchard, 'Election Petitions and the Standard of Proof' (2015) 27 Denning Law Journal 291.

${ }^{23}$ The Law Society (n 4) para 2.5.

${ }^{24}$ For example, Rule 17 of the Rules of Procedure of the International Association of Athletics Federations' Ethics Commission provides that 'The standard of proof in all cases shall be determined on a sliding scale from, at minimum, a mere balance of probability (for the least serious violation) up to proof beyond a reasonable doubt (for the most serious violation). The Panel shall determine the applicable standard of proof in each case'. See International Association of Athletics Federations, 'Code of Ethics' (IAAF, January 2015) <https://www.iaafethicsboard.org/Content/downloads/IAAFCode-of-Ethics-eng.pdf $>$ accessed 10 June 2019.

25 Solicitors Regulation Authority v Solicitors Disciplinary Tribunal (n 6) para 49. 


\section{THE STANDARD OF PROOF IN DISCIPLINARY PROCEEDINGS: SOLICITORS REGULATION AUTHORITY v SHARIF (2019)}

arguably, even in such cases, this does not require the adoption of the criminal standard. The views expressed in the Arslan case (noted earlier) that the "climate and approach to professional regulation has changed ${ }^{26}$ and that there is a need for 'a re-evaluation of the approach to disciplinary measures intended to protect the public ${ }^{27}$ emphasise the point. Further, in the Sharif case itself, the Solicitors Disciplinary Tribunal emphasised that "maintaining public confidence in the profession remains of paramount importance'. ${ }^{28}$ The failure of Mr Sharif to comply with his anti-money laundering obligations highlights the concern.

Given these strong statements, it is difficult to justify the retention of the criminal standard of proof in disciplinary cases before the Solicitors Disciplinary Tribunal. The solution does not lie in the adoption of an intermediate standard. Instead, while emphasising that there is a single civil standard of proof, the English courts have supported a 'flexible' application of that standard. Thus in In re CD (Original Respondent and Cross-appellant) (Northern Ireland) ${ }^{29}$ Lord Carswell opined that the proposition neatly expressed by Richards LJ in $R(N) v$ Mental Health Review Tribunal (Northern Region) ${ }^{30}$ 'effectively states in concise terms the proper state of the law on this topic': ${ }^{31}$

Although there is a single civil standard of proof on the balance of probabilities, it is flexible in its application. In particular, the more serious the allegation or the more serious the consequences if the allegation is proved, the stronger must be the evidence before a court will find the allegation proved on the balance of probabilities. Thus the flexibility of the standard lies not in any adjustment to the degree of probability required for an allegation to be proved (such that a more serious allegation has to be proved to a higher degree of probability), but in the strength or quality of the evidence that will in practice be required for an allegation to be proved on the balance of probabilities. ${ }^{32}$

26 Solicitors Regulation Authority v Solicitors Disciplinary Tribunal (n 6) para 49.

27 Ibid., para 73.

28 Solicitors Regulation Authority v Sharif (n 2) para 29.

29 In re CD (Original Respondent and Cross-appellant) (Northern Ireland) [2008] UKHL 33.

${ }^{30} R(N) v$ Mental Health Review Tribunal (Northern Region) [2005] EWCA Civ 1605, para 62 .

31 In re CD (Original Respondent and Cross-appellant) (Northern Ireland) (n 30) para 27.

32 Ibid. 
Lord Carswell further noted 'that in some contexts a court or tribunal has to look at the facts more critically or more anxiously than in others before it can be satisfied to the requisite standard.... ${ }^{33}$ Thus situations 'which make such heightened examination necessary may be the inherent unlikelihood of the occurrence taking place..., the seriousness of the allegation to be proved or, in some cases, the consequences which could follow from acceptance of proof of the relevant fact'. ${ }^{34}$

This is surely the correct approach. Thus in cases before both the Solicitors Regulation Authority and the Solicitors Disciplinary Tribunal, the civil standard of proof should be applied. However in cases before the Tribunal in which there are very serious allegations of misconduct which, if proved, could subject the solicitor to the possibility of an unlimited fine or removal from practice, the Tribunal must require more cogent evidence to support the allegations. This would protect both the public interest and the interest of the individual solicitor.

It is now up to the Law Society to follow the lead of the Bar Standards Board.

\footnotetext{
33 Ibid., para 28.

${ }^{34}$ Ibid. Lord Carswell gave a useful illustration which might also apply to the position of a solicitor: 'The seriousness of consequences is another facet of the same proposition: if it is alleged that a bank manager has committed a minor peculation, that could entail very serious consequences for his career, so making it the less likely that he would risk doing such a thing': Ibid. See also the views of the Privy Council in Hearing on the Report of the Chief Justice of Gibraltar [2009] UKPC 43 esp pp 15-17.
} 